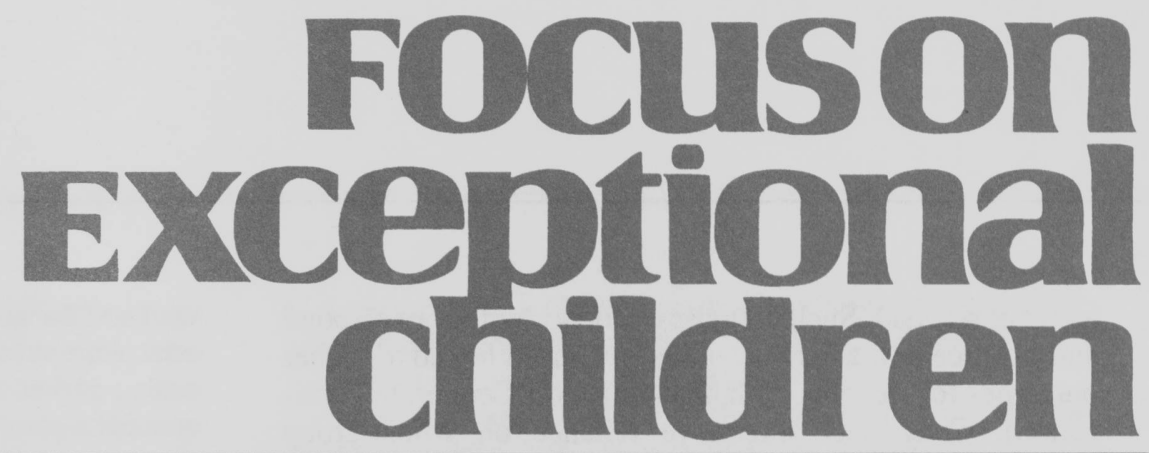

\title{
Cooperative Learning as an Academic Intervention for Students with Mild Disabilities
}

\author{
Kimber W. Malmgren
}

A current trend in education is toward the inclusion of students with special needs in general education classrooms. This trend grew out of the regular education initiative (REI), which started with the goal of educating larger numbers of students with mild disabilities in the general education environment to increase the overall academic achievement in schools (Lewis, Chard, \& Scott, 1994). Over time, the objective of inclusive programming has grown-from simply increasing academic achievement to also increasing social competence and fostering positive relationships between children with special needs and their nonhandicapped peers. Thus, not only are contemporary teachers educating more diverse groups of students, but their responsibilities also are expanding to include more and more objectives. Teachers of students with mild disabilities must somehow facilitate the simultaneous attainment of academic and social skill goals alike- both of which represent significant areas of need for students with learning and behavioral disabilities.

How teachers choose to meet this challenge varies - but teachers in inclusive environments typically choose interventions that are not only effective, but efficient as well. Teachers understandably feel pressure to focus primarily on academic skills even as they take on responsibility for more and more nonacademic (social) skills as well. Although robust literature is available on interventions that affect social behavior, programs and strategies that do not also directly impact academic skills in some way are viewed as "addons" and not typically maintained by teachers in general education settings (Fullan, 1991; Johnson, 1970, 1979).

Increasingly, various forms of small-group instruction-specifically, models of cooperative learning - are being recommended as solutions for the complex problems associated with attempting to provide special, "individualized" education to students with learning and behavior problems in general education settings. Facets of these strategies as they influence the academic success of students with mild disabilities are discussed in this article, along with excerpts from interviews and observations done as part of a study of cooperative learning practices in an urban school district in the Pacific Northwest (Malmgren, 1997).

\section{SMALL GROUP INSTRUCTION}

Small-group instruction-as opposed to whole-group instruction-is an instructional arrangement wherein students within a class are divided into groups for the purpose of learning (Lou et al., 1996). For teachers in general education classrooms, small-group instruction is a practical teaching strategy for many reasons. Utilizing small-group instruction enables teachers to increase instructional time and students to have opportunities to

Kimber Malmgren is affiliated with the Department of Special Education, University of Maryland, College Park. 
actively respond. Such increases in opportunities to respond and practice new academic skills have been linked to higher outcomes for students with disabilities (O'Connor, in publication). Conversely, excessive reliance on whole-group instruction and individual seatwork sets the stage for offtask behavior by students who, to be productive, need instructional guidance.

Another benefit of small-group instruction is that it increases a teacher's ability to individualize instruction-a necessary but challenging prospect for teachers who are charged with delivering "special education" in a large-group setting. With students working in small groups, teachers are free to give instructions or explanations to the whole class or just to specific groups. This arrangement also allows teachers to easily vary assignments or instructions within the larger group. The merit of this aspect of small-group instruction is punctuated by Lou et al.'s (1996) finding in their metaanalysis of group instruction that effect sizes were higher when teachers individualized instructional materials across groups.

$$
* * *
$$

Ms. Tanin, a former self-contained special education teacher, began her first year as a general educator in one of three inclusive primary classrooms in the inner-city school in which she

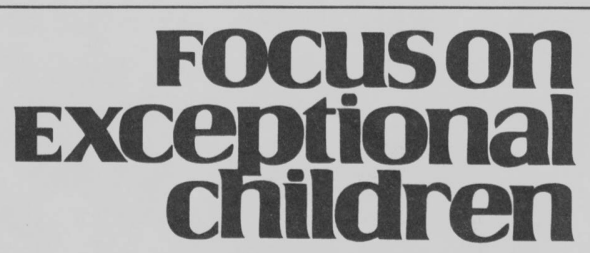

ISSN 0015-511X FOCUS ON EXCEPTIONAL CHILDREN (USPS 203-360) is published monthly except June, July, and August as a service to teachers, special educators, curriculum specialists, administrators, and those concerned with the special education of exceptional children. This publication is annotated and indexed by the ERIC Clearinghouse on Handicapped and Gifted children for publication in the monthly Current Index to Journals in Education (CIJE) and the quarterly index, Exceptional Children Education Resources (ECER). The full text of Focus on Exceptional Children is also available in the electronic versions of the Education Index. It is also available in microfilm from Xerox University Microfilms, Ann Arbor, MI. Subscription rates: Individual, $\$ 30$ per year; institutions, \$40 per year. Copyright (c) 1998, Love Publishing Company. All rights reserved. Reproduction in whole or part without written permission is prohibited. Printed in the United States of America. Periodicals postage is paid at Denver, Colorado. POSTMASTER: Send address changes to:

\footnotetext{
Love Publishing Company Executive and Editorial Office 9101 E. Kenyon Ave., Suite 2200

Denver, Colorado 80237

Telephone (303) 221-7333
}

Edward L. Meyen

University of Kansas
Glenn A. Vergason Georgia State University
Richard J. Whelan

University of Kansas Medical Center worked. Because of her background in working with special education students, Ms. Tanin was assigned a class roll consisting of five students with special needs (learning disabilities and behavioral disorders) along with her roster of 20 general education students.

Early in the year, Ms. Tanin became frustrated in her efforts to teach science as a whole-group activity. Getting through one unit had been time-consuming because of the frequency with which she had to interrupt her teaching to redirect students who were off-task. She also was frustrated by her realization that a fraction of her students already had been exposed to some of the content and did not actually have the opportunity to significantly add to their knowledge base, while others were operating at a rudimentary level and seemed to be lost during wholegroup discussions. She felt a professional obligation to give individual assistance to students who qualified for special education services, yet thought the larger group suffered when she spent too much class time working with individual students. When it became time to start a new science unit-this one on liquids-Ms. Tanin decided to use cooperative small-group instruction as her primary teaching method.

\section{THEORETICAL RATIONALE}

The theoretical rationale for small-group instruction as a strategy for increasing academic achievement centers upon the interaction among peers around academic tasks. Vygotsky defined the zone of proximal development as "the distance between the actual developmental level as determined by independent problem solving and the level of potential development as determined through problem solving under adult guidance or in collaboration with more capable peers" (1978, p. 86).

According to Vygotsky, working in a heterogeneous group of peers promotes learning for low achievers because the higher achieving peers are modeling behaviors more advanced than the low achievers could achieve on their own, but still within their zone of proximal development. Vygotsky stresses the importance of collaboration among learners in that "functions are first formed in the collective in the form of relations among children and then become mental functions for the individual" (1978, p. 47). Even arguing is viewed as positive in that it gives rise to reflection.

In a similar vein, Piaget (1926) held that social-arbitrary knowledge (which includes reading and math) can be learned only through interaction with others. According to Piagetian theorists, peer interaction allows children who have yet to master a certain principle (e.g., conservation) develop that concept by collaborating with more advanced peers on tasks requiring knowledge of that concept for success. Discussions give rise to conflicts in which inadequate reasoning is exposed-allowing higher-quality understandings to emerge (Wadsworth, 1984).

Whereas Vygotskian (Vygotsky, 1978) and Piagetian (Piaget, 1926) theories of learning stress the benefit to lowachievers in small-group, peer-mediated instructional settings, research in cognitive psychology points to benefits for
Stanley F. Love Publisher

Thomas S. Love Associate Editor 
high-achievers in small-group settings as well. When learners engage in cognitive restructuring, or elaboration of material (e.g., explaining a concept to a less-abled peer), that material is better retained and related to other information already in the learner's memory (Wittrock, 1978). The benefits of explaining material to someone else have been well documented in research on tutoring as well (e.g., DevinSheehan, Feldman, \& Allen, 1976).

Small-group instruction is also thought to improve social relations among heterogeneous peers. Gordon Allport's (1954) contact theory of intergroup relations holds that when individuals of different backgrounds work together on an equal footing to achieve common goals and get to know one another as individuals, they shed their prejudices and friendships may evolve. Although not all forms of smallgroup instruction provide a platform for students to work toward a common goal with equal opportunities for success, those that do certainly meet the requirements for promoting positive relations under Allport's theory.

Allport's contact theory was developed with interracial interaction in mind.

Recent researchers (e.g., Slavin \& Stevens, 1991) have extended Alport's contact theory of interracial interaction to improving relations between general education students and their mainstreamed special education classmates. This is an important point because mainstreamed special education students have been found to be less well accepted and more frequently rejected on sociometric measures than their general education peers (e.g. Clever, Bear, \& Juvonen, 1992; Larrivee \& Horne, 1991).

$$
* * *
$$

Jasmine slowly poured corn syrup into a ziplock bag, stopping every few seconds to tip the container upright and note the level of the remaining corn syrup. Lorenzo, who was waiting for his turn, squirmed in his seat and chastised Jasmine: "Hurry up, stupid! You know it's going to be the same as the last one! Just POUR it!"

Jasmine glared at Lorenzo, but before she could retort, a third group member, Tyler, intervened: "Look, Lorenzo, Jasmine can do it any way she wants. Anyway-you're supposed to be drawing a picture of the other tubes."

Lorenzo: "I'm sick of this!"

Tyler: "Here-look at my picture. I even drew the bubbles in. You can copy mine if you want."

Lorenzo bent his head over his page to copy, while Jasmine went back to pouring. As the teacher walked by, Tyler blurted out, "Hey, look at us Ms. Tanin!"

Ms. Tanin smiled and assured the group that they were earning lots of Boat Bucks. Ms. Tanin moved on as Jasmine finished pouring.

Jasmine: "Look there, Lorenzo. The syrup is NOT at the same level as the oil! It's a good thing I was so careful."

Lorenzo snatched the ziplock back from Jasmine. "Hey, how can that be!"

Amber, who had been holding the ziplock open for Jasmine and now studied the tubes of liquids, interjected: "Look herethe tubes are different sizes to begin with."
Lorenzo: "No way!" He snatched a tube from Amber and compared it to the one in front of him. "Look at this! Mine's skinnier!" Jasmine: "I bet yours will be a higher level, too."

Lorenzo looked pensively at the tube in front of him, then finally responded. "No, I think mine will be a lower level because there can't be as much in here because it's skinnier."

Tyler: "Okay, Lorenzo, it's your turn. Amber, do you want to hold the baggie for him?"

Ms. Tanin, who had been listening from a few feet away, smiled. She was especially happy with this group's functioning because Lorenzo, who was labeled as having a specific learning disability and also has significant behavioral deficits, did not usually interact, positively or otherwise, with his fellow classmates.

$$
* * *
$$

\section{MAXIMIZING POSITIVE OUTCOMES FOR STUDENTS WITH MILD DISABILITIES}

The effectiveness of small-group instruction for students with mild disabilities - and, for that matter, students of any type - can be hindered or fostered depending on the specific characteristics of the groupwork. Group composition, nature of the group task, and relative ability of group members can have a significant impact on increases in task-related interactions and increases in academic achievement.

\section{Group Composition}

The decision to place students in heterogeneous versus homogeneous ability groups depends on the nature of the learning task (Noddings, 1989). With regard to subject area of instruction, a recent meta-analysis of within-class grouping found that overall effect sizes for homogeneous and heterogeneous ability instructional groups in mathematics and science were not significantly different; in reading, however, homogeneous ability groups were superior (Lou et al., 1996). This may be because tasks in math and science are typically more hierarchical and, thus, discussion with and assistance from peers of varying abilities may be more likely to benefit student progress (Lou et al.).

Lou et al.'s (1996) meta-analysis also determined that the effects of homogeneous versus heterogeneous groups were not stable across student ability. Low-ability students learned significantly more in heterogeneous groups, regardless of subject matter. This is most likely because lowachievers have the most to gain from peer interaction around learning tasks. Low-achievers in homogeneous groups lack models of more capable thinkers, as well as peers who can stretch their learning by pushing the limits of their zones of proximal development.

Because most students with learning disabilities and behavioral disorders have academic deficiencies, academic growth for these students likely will be maximized by their participating in heterogeneous ability groups during smallgroup instruction-especially in the areas of math and science. Also, if Allport's (1954) contact theory can be applied 
to relations between mainstream and special education students, small groups composed of students from both of these categories will produce increases in positive interactions between them.

$$
* * *
$$

When Ms. Tanin sat down to devise the small groups for her upcoming science unit, she kept in mind that academically diverse groupings are ideal. Her class, however, has a disproportionate number of "low achievers." Instead of grouping students strictly by achievement level, she grouped them with an eye toward their individual strengths.

When she was forced to compromise the academic heterogeneity of a group by placing two (or more) low-achieving students together, she considered other traits as well. Group B, for instance, consisted of two students who were reading two years below grade level. One of the students had high comprehension skills and would be an asset to the group when it came time to deduct meaning from their experiments. The other lowreader was patient and caring and would serve as a positive influence over the third member of the group, who tended to be argumentative and quick to anger. Ms. Tanin avoided obviously volatile combinations of students-but she also avoided grouping cliques of friends together so as to encourage interaction among students who otherwise might not allow themselves that opportunity.

\section{$* * *$}

\section{Positive interdependence}

Positive interdependence-referred to simply as the use of "group goals" in some cooperative learning literatureexists when individual students perceive that their accomplishments contribute positively to the accomplishments of others. When students in small groups are recognized for the accomplishments of their group as a whole, positive interdependence is in place and the learning is considered cooperative. When students are physically placed into small groups for instruction but no structure is in place for positive interdependence, the learning is considered competitive or individualistic in nature. Students working toward a collaborative or group goal have been found to develop concepts that are richer and more precise than groups of students who work independently under competitive or individualistic goal structures (Kol'tsova, 1978).

Ensuring that students work toward a group goal is best facilitated by ensuring that groups are given group tasks. A group task is one that requires some type of input from all the group members for the group to be successful (Cohen, 1994). A task given to a group that an individual could easily carry out does not create positive interdependence. This type of task is not likely to facilitate interaction for all group members-particularly low-ability students who may be perceived by their groupmates as having little to offer or students who are rejected socially. To circumvent this problem, Cohen and Cohen (1991) suggest utilizing a classroom management system that encourages students to be responsible for each others' success, issuing specific roles during groupwork to help ensure that groups function in a prespecified manner, and utilizing ill-structured tasks (ones that do not have a single correct answer) for the groups to collaborate on.

Positive interdependence in small groupwork can be created in many ways. The most effective way is to set up a situation in which all group members receive a reward when the group collectively has met some standard. In behavioral literature this concept is referred to as an interdependent group contingency. When an interdependent group contingency is set up, student group members will encourage and even punish each other to ensure that the group is successful. Instigating an interdependent group contingency has the added effect of ensuring that all group members actively participate and thus have the chance to benefit academically.

According to Slavin (1995), this is the best way to avoid small-groupwork in which one or more members "slack off" or groupwork in which low-status or low-ability students are discouraged from participating. By making increased achievement the group goal for all members and by rewarding groups that accomplish their goal (i.e., reward interdependence), all members of a group will be more likely to interact, maximizing academic growth for all. Various researchers supported this notion, reporting that the greatest effects of cooperative learning come when groups are rewarded for the increased achievement of all the members of their groups (Davidson, 1985; Ellis \& Fouts, 1993; Manning \& Lucking, 1991; Slavin, 1983).

Overall, positive interdependence that is established by utilizing group rewards in conjunction with group goals maximizes the positive effects of small-group instruction on academic growth for all students. Tudge (1992) contends that adding these factors to groupwork introduces the element of motivation that is lacking in most work in the Vygotskian and Piagetian traditions. He views this as a step in the direction of acknowledging that contextual factors also influence learning when peers come together around academic tasks.

As an example- - how much two children's zones of proximal development overlap may not matter if they simply refuse to speak to each other. Explicit group goals and group rewards provide the motivation for the valuable interaction to take place. This distinction may be especially relevant for students with behavioral disorders who are prime candidates for missing the benefits of task-related peer interaction if they are left in small groups with little structure and who traditionally have responded well to behavioral interventions.

$$
* * *
$$

Before beginning the new unit on liquids, Ms. Tanin spent one entire class period describing her expectations for the coming groupwork and laying ground rules with her students regarding acceptable behavior for cooperative learning activities. In addition to the layer of everyday rules and expectations, Ms. Tanin set up a special contingency just for cooperative groupwork.

In keeping with the theme of the unit, Ms. Tanin had chosen a culminating activity in which the students would build boats 
for a classwide regatta. Supplies for the boats were placed on display and students were informed that they could be "purchased" from Ms. Tanin with "Boat Bucks." These Boat Bucks were to be awarded to groups depending upon their performance on weekly quizzes. Boat Bucks would be distributed to groups, not individuals.

Therefore, to purchase the most desirable supplies, students were encouraged to help each other in preparing for the weekly quizzes. All groups would receive Boat Bucks each week; the variation was simply in how many. Also, all the supplies were sufficient to go around, to avoid encouraging cutthroat competition between groups for scarce resources. Ms. Tanin wanted the groupwork rewards to be reinforcing without creating stakes that were so high as to cause anxiety.

$$
* * *
$$

\section{Equal Opportunities for Success}

Familiarity and attraction between peers in a group has been shown to impact the quality of the interactions that take place in that group (Cohen, 1982). Utilizing a group goal and group reward is one step toward minimizing the negative impact of groups made up of children who perceive themselves to be dissimilar to each other. Allport's (1954) contact theory of intergroup relations points out, however, that this may not be enough.

Quality interactions may not take place unless all children in the group believe they have an equal opportunity to succeed. If tasks are structured in such a way that certain members of the group can succeed more easily than others, the stage for further divisiveness may have been set. Placing students in heterogeneous-ability cooperative learning groups will not necessarily lead to an increase in positive interactions unless some structure is built into the activity to ensure an "even playing field." Creating group tasks in which all students believe they can contribute to the good of the group helps promote acceptance, leads to more positive interactions, and, hopefully, to increased achievement.

Some specific manifestations of cooperative learning have these structures. For example, researchers at Johns Hopkins University have developed cooperative learning techniques that allow students to contribute to their group's goal by improving their own past performance. In these methods, group rewards are awarded to groups based on the extent to which members meet or exceed their own earlier levels of achievement. These methods prevent group members from viewing low-achieving students as burdensome and promote acceptance of mainstreamed special education students (Madden \& Slavin, 1983; Slavin, 1984).

Because students with behavioral disorders and learning disabilities are typically low-achievers, increases in positive peer interactions resulting from participation in cooperative learning groups should be maximized in methods that provide equal opportunities for success for all students. Increases in peer interactions then should lead to better understanding of the academic content around which the interactions take place.
$* * *$

Toward the end of the first week of the unit on liquids, students began preparing for their first quiz. Over the course of the week, the students had come up with a list of properties that various liquids share, as well as a list of differences between the liquids they had studied. The students were to be quizzed on their knowledge of these traits on the coming Friday. Groups would be awarded Boat Bucks depending on the performance of all of the members.

Surveying the room as the students quizzed each other in their small groups, Ms. Tanin noticed that Aaron, one of her students with a learning disability, was sitting to the side by himself. Ms. Tanin approached the group and reminded the members that everyone should participate for the group to earn the maximum amount of Boat Bucks. The three group members who had been working actively on the assignment looked guiltily at Aaron. Aaron got up glumly and joined the group but simply laid his head on the table, saying he felt sick.

The next day-which was quiz day-Aaron was absent from school. Ms. Tanin had the sinking feeling that he had elected to stay home to avoid the pressure of the science quiz and the possibility that he might bring down his group with a low score. A weekend call to his mother and a Monday morning conference with Aaron himself convinced Ms. Tanin that her suspicions were justified. Although Aaron had participated actively in the science lessons all week and seemed to be learning as much as his group mates, he feared that his difficulty with spelling would prevent him from earning a high score on the quiz.

Although Ms. Tanin's lesson plans incorporated the elements of "positive interdependence" (the success of the group hinged on the success of every member) and "individual accountability" (meaning that each student was individually accountable for learning the material), she had failed to provide "equal opportunities for success." Aaron had more obstacles to overcome than his groupmates did (i.e., his difficulty with spelling in addition to learning the content) in getting a good grade on the quiz. For the next quiz, Ms. Tanin arranged for Aaron (and one other student) to dictate his answers to the instructional assistant so as to create a more fair (and less threatening) learning environment.

$$
* * *
$$

To create cooperative learning activities that provide special-needs students with equal opportunities for success, teachers sometimes have to be highly creative. When using a cooperative learning method such as Slavin's (1995) Student Teams Achievement Divisions, groups are rewarded for their joint performance on quizzes-but students add to their group's performance depending on how much they improve from their previous quiz score. This allows students to compete with themselves rather than feeling like they all must meet the same criteria to be deemed successful.

Other forms of cooperative learning produce equal opportunities for success by allowing for alternative forms of assessment or by using group projects that allow for multiple forms of contribution (e.g., one person draws, one acts out, one summarizes, and so on) as assessment activities. In 
these ways, students are allowed to contribute according to their strengths while everyone is still held responsible for learning and demonstrating that learning.

\section{OBSTACLES TO EFFECTIVE COOPERATIVE LEARNING GROUPWORK}

An issue that is germane to students with special need but of almost negligible concern in the education of nondisabled students is fragmentation. Students with mild disabilities being educated in general classrooms are frequently pulled out of class to receive related services (such as counseling or speech therapy) or undergo IEP testing. In addition to special education-related disruptions, behavioral difficulties also lead to students' missing class time. Whether a student stays after recess to work out a problem with the recess supervisor or spends several minutes in a time-out area, problematic behavior detracts from these students' learning of academic content. Missing a teacher's introductory comments or being pulled out of class prior to a wrap-up activity is especially detrimental to students with mild disabilities who have difficulty processing information, focusing on the task at hand, or picking out the critical elements from an abstract or experiential lesson.

Even though these issues are relevant for students with mild disabilities throughout the school day, additional obstacles are presented when students miss time allotted to cooperative groupwork. Part of the appeal and strength of cooperative learning is that students learn social skills from relating to each other in structured activities with guidance from their teacher. Along with these social skills and taskrelated interactions come increases in academic achievement attributable, at least in part, to the dependence that group members feel on each other's success. When cooperative learning group members view themselves as a cohesive unit, they develop an "all for one" mentality that spurs them to actively pursue success for each and every member.

Positive interdependence set in place by a group reward that is awarded based upon the actions and achievement of the group as a whole promotes a certain level of caring among group members. When students are chronically absent or miss significant portions of class time, for either academic or disciplinary reasons, that student's ability to bond with groupmates is jeopardized. The academic benefits reaped from increased peer interactions then are compromised.

$$
* * *
$$

Keesha, Madeline, and Kenneth came in from recess and settled into their places for science. They already knew that today's lesson would involve creating vessels from clay to see what type of design could hold the most paper clips. They were excited about the lesson and eager to begin, using the materials that Ms. Tanin had already laid out at their table.

Keesha: "Where's Nate?"

Kenneth: "I don't know. Let's start without him." Kenneth began tearing apart the block of clay into four equal pieces.

Keesha yelled out: "Ms. Tanin! Where's Nate?"
Ms. Tanin held up her hand toward Keesha as a signal not to yell across the room while she gathered the attention of the class. Ms. Tanin reviewed that group members first would experiment with their own individually designed vessels, then would take turns improving on the design of a group vessel. She reminded the students (as she did before each lesson) of her expectations and the criteria for earning Boat Bucks.

Just as she finished, Nate entered the classroom, escorted by a recess monitor who waved to Ms. Tanin from the back of the room and placed a note on her desk before leaving. Nate sat down at his place and slumped, dejected, in his chair. Kenneth pushed a piece of clay toward Nate: "Here. Make a boat." Keesha quizzed Nate about what happened at recess while Kenneth and Madeline began manipulating their lumps of clay.

A few minutes later Ms. Tanin called Nate to her desk. Keesha, Kenneth, and Madeline went on with their work. Because of an altercation at recess, Nate was being asked to write an apology note to a student in another class. Ms. Tanin asked Nate to sit at her desk and write the apology note while she worked her way around the room checking on the various groups. Eventually Nate completed his note and was allowed to rejoin his group.

After only a few minutes, Ms. Tanin gained the whole group's attention and informed the members that it was time to work on their group-designed vessels. Nate, who had not yet had a chance to create his own vessel, continued working with his own piece of clay even though Kenneth was trying to reclaim the individual pieces of clay for the group vessel.

Just as Kenneth was becoming visibly frustrated with Nate, Madeline intervened: "Just leave it. We'll make our boat with what's left,"

Kenneth: "But that's not fair! The other groups will have more clay!"

Keesha solved the problem by retrieving more clay from the supply table without Ms. Tanin's noticing. Keesha, Madeline, and Kenneth continued with the project-passing their clay vessel around to each other, making subtle improvements in the design after each test in the water, and noting the results in their group science log.

Finally Nate was ready to relinquish his individual piece of clay to join in the work of the other three. When Madeline passed the group vessel to Nate for him to make an adjustment, Nate balled up the vessel by pounding it on the table to start over. All three of his groupmates howled.

Kenneth: "What are you doing!? You're supposed to improve it, not smash it!"

Ms. Tanin arrived to help diffuse the problem. Kenneth complained to Ms. Tanin: "Do we have to have him in our group? He doesn't even know what we're supposed to be doing!"

Ms. Tanin calmed Kenneth then asked Madeline, Kenneth, and Keesha to explain the directions to Nate again. Before they could finish explaining the directions to Nate, Nate's social worker peeked through the door. Today was Thursday, which meant that Nate would be leaving early. Ms. Tanin sighed and instructed Nate's groupmates to go ahead and proceed without him. Sulking, Nate gathered his belongings and prepared to leave. 


\section{CLASSROOM MANAGEMENT}

Cooperative learning groups are thought to increase achievement for low-achievers because they allow children to interact with more capable peers around academic tasks. Even though disagreements and differences of opinions can be constructive in these types of learning arrangements, excessive antisocial behavior can impede a group's functioning. Many prominent cooperative learning researchers (e.g., Cohen, 1994; Dishon \& O’Leary, 1984; Slavin, 1995) acknowledge that even well planned group interventions do not always function smoothly enough for learning to take place. Students with behavior disorders-who are prone to antisocial behavior-possibly may display actions in cooperative learning settings that prevent them from receiving the same benefits that other populations of students do. Constructing cooperative learning groups and tasks that best suit low-achievers who differ from the majority of their peers will minimize the possibility of failure for students with mild disabilities.

Instigating cooperative learning groupwork represents a shift in the power structure of a typical classroom. Whereas teachers typically are "in charge" of instruction and are used to controlling discussion and keeping an eye out for discipline problems, breaking up the classroom into small groups for instruction means that a classroom will be functioning as five, six, or even more separate factions. The teacher's role shifts from leader to moderator and trouble-shooter. At first this shift in structure can feel disconcerting to teachersand sometimes for their students as well. Even the most seasoned teachers can feel a threatening loss of control when they first turn their classrooms into cooperative groupings.

$$
* * *
$$

Remembering her first day of cooperative groupwork, Ms. Tanin chuckles about the anxiety she felt as the children came in from recess and noisily found their seats-which had been rearranged into clusters of four for the upcoming lesson. In the first cooperative lesson, the children were to manipulate tubes of various liquids to make observations and predictions about their properties. Materials already were set out for the groups, and the group members' roles had been preselected. Even though Ms. Tanin had explained the activity and the roles to the students before recess, they were bickering over who would be the facilitator and who would get to handle the tubes of liquids first.

Ms. Tanin gained the attention of the class (with some difficulty) and repeated the directions for the activity. She solicited ideas from class members for ways of solving problems and sharing materials, and she reminded everyone that Boat Bucks would be rewarded to groups, not individuals. A few of her students needed frequent external reinforcement, so she decided on the spot to announce that Boat Bucks would be awarded daily to groups that were able to follow the rules established earlier in the week for group functioning. Seeing that some groups had settled immediately into a negative routine made her realize that staving off the group reward until the day of the quiz (which was several days off) would be too much delay for some of her students. For the Boat Bucks to hold any power, she would have to award them more frequently. She turned the class back to the groups and immediately began to question the wisdom of using cooperative groups with her class:

"I was thinking, 'Oh brother, what have I got myself into?' Maybe this works in a regular class, but not with my kids! l've got too many kids with behavior problems-identified and otherwise. Usually in class when someone calls another kid a name, I can reprimand the student. I've got everyone's attention, and I can easily see what's going on in the room. Now, with six separate groups, l've got six separate sets of name-calling going on simultaneously! I had no way to intervene! I felt like I was just putting out fire after fire."

At the end of the lesson, Ms. Tanin got everyone's attention to summarize the day's lesson and to make a formal presentation of the Boat Bucks to the various groups. She announced that each group could earn a total of five Boat Bucks. She reviewed the groupwork rules that had been established earlier and functioned as her criteria for awarding Boat Bucks. She awarded two groups two Boat Bucks each. She awarded the other four groups one each. The class was silent with disappointment.

The next day, before recess, Ms. Tanin previewed the upcoming science lesson and reminded everyone that just getting situated and on-task efficiently would be enough to earn each group one Boat Buck. She reviewed the rest of the groupwork rules and reminded the class that adhering to each rulewhether it be, "Ask your groupmates for help before asking the teacher" or, "Treat each other with respect"-would equate to Boat Bucks. Even though the small groups did not function ideally that second day, they did function better. Ms. Tanin went from thinking she had made a grave mistake on the first day to proudly showing off her students and their accomplishments to visitors two weeks into the unit.

$$
* * *
$$

\section{CONCLUSION}

The example of cooperative learning excerpted above is a positive one, chosen to illustrate various points. Even in the study from which this example was drawn-in which other teachers used the exact same lesson plans as Ms. Tanin with similar groups of children - the results for other teachers were not identical. In some cases teachers had difficulty setting up an environment in which students with mild disabilities were accepted as equal members of their groups. In one classroom the chaos of that first lesson did not subside but, instead, increased to the point at which the teacher gave up cooperative learning groups in the middle of the unit. In these cases the problems stemmed not from the teaching strategy itself but, rather, from problems in the way it was carried out. For cooperative learning groups to be successful for students with learning and behavioral difficulties in general classrooms, several things must be in place.

1. Care must be taken in creating the small groups. Groups should be academically heterogeneous, taking 
care to ensure that conflicting personalities don't cause unnecessary problems.

2. The tasks assigned to the groups must be cooperative in nature and lend themselves well to group completion.

3. Positive interdependence must exist, meaning that tasks and assessments should be designed in such a way that everyone has to contribute something for the group as a whole to be rewarded.

4. Group members must have individual accountability; each student should be held responsible for learning the content.

5. The teacher must provide equal opportunities for success, meaning that students with mild disabilities should be able to contribute to the group's success in a way that does not cause them undue hardship.

6. Scheduling must be considered to ensure that students, especially those with disabilities, do not miss blocks of time that has been allocated for groupwork. Reaping the benefits of cooperative learning is difficult when a student is not present or when his or her participation is fragmented.

7. General classroom management must be ongoing. Turning over a class to groupwork does not resolve classroom management problems, and may actually exacerbate some. Teachers must set ground rules, make them obvious to the students, and be sure to administer reinforcers frequently enough to be effective. Teachers should endeavor to ensure that all students have fun and feel successful.

Cooperative learning has potential as a powerful teaching strategy in inclusive classrooms, impacting both academic and social skills. Cooperative groupwork creates new opportunities for students to respond and practice new skills by allowing students to learn through interactions with their peers. In addition, teachers can improve their ability to individualize work for a wide range of students with varying abilities by focusing on a handful of groups instead of a myriad of individuals. Although obstacles to the positive functioning of cooperative learning groups in inclusive classrooms are plentiful, success is possible for teachers who implement the strategy with thoughtfulness and care.

\section{REFERENCES}

Allport, G. (1954). The nature of prejudice. Cambridge, MA: AddisonWesley.

Clever, A., Bear, G., \& Juvonen, J. (1992). Discrepancies between competence and importance in self-perceptions of children in integrated classes. Journal of Special Education, 26, 125-138.

Cohen, B. P., \& Cohen, E. G. (1991). From groupwork among children to R\&D teams: Interdependence, interaction and productivity. Advances in Group Processes, 8, 205-226.

Cohen, E. G. (1982). Expectation states and interracial interaction in school settings. Annual Review of Sociology, 8, 109-235.

Cohen, E. G. (1994). Restructuring the classroom: Conditions for productive small groups. Washington, DC: Office of Educational Research and Improvement. (ERIC Document Reproduction Service No. ED $347639)$
Davidson, N. (1985). Small-group learning and teaching in mathematics: A selective review of the research. In R. E. Slavin, S. Sharan, S. Kagan, R. Hertz-Lazarowitz, C. Webb, and R. Schmuck (Eds.), Learning to cooperative, cooperating to learn (pp. 211-230). New York: Plenum.

Devin-Sheehan, L., Feldman, R., \& Allen, V. (1976). Research on children tutoring children: A critical review. Review of Educational Research, 46, 355-385.

Dishon, D., \& O’Leary, P. W. (1984). A guidebook for cooperative learning. Portage, MI: Cooperation Unlimited.

Ellis, A. K., \& Fouts, J. T. (1993). Research on educational innovations. Princeton Junction, NJ: Eye on Education.

Fullan, M., with Stiegelbauer, S. (1991). The new meaning of educational change. New York: Teachers College Press.

Johnson, D. W. (1970). Social psychology of education. New York: Holt, Rinehart \& Winston.

Johnson, D. W. (1979). Educational psychology. Englewood Cliffs, NJ: Prentice Hall.

Kol'tsova, V. A. (1978). Experimental study of cognitive activity in communication (with specific reference to concept formation). Soviet Psychology, 17(1), 23-38.

Larrivee, B., \& Horne, M. D. (1991). Social status: A comparison of mainstreamed students with peers of different ability levels. Journal of Special Education, 25, 90-101.

Lewis, T. J., Chard, D., \& Scott, T. M. (1994). Full inclusion and the education of children and youth emotional and behavioral disorders. Behavioral Disorders, 19, 277-293.

Lou, Y., Abrami, P. C., Spence, J. C., Poulsen, C., Chambers, B., \& d'Apollonia, S. (1996). Within-class grouping: A meta-analysis. Review of Educational Research, 66, 423-458.

Madden, N. A., \& Slavin, R. E. (1983). Effects of cooperative learning on the social acceptance of mainstreamed academically handicapped students. Journal of Special Education, 17, 171-182.

Malmgren, K. W. (1997). Cooperative learning as an academic intervention for students with behavioral disorders. Unpublished doctoral dissertation, University of Washington, Seattle.

Manning, M. L., \& Lucking, R. (1991). The what, why, and how of cooperative learning. Social Studies, 82, May/June, 120-124.

Noddings, N. (1989). Theoretical and practical concerns about small groups in mathematics. Elementary School Journal, 89, 607-623.

O'Connor, R. (in publication). Curriculum, instruction, support, and organizational arrangements in elementary schools for children with mild disabilities and learning difficulties. In M. Reynolds, M. Wang, \& H. Walberg (Eds.), Handbook of special education.

Piaget, J. (1926). The language and thought of the child. New York: Harcourt, Brace.

Slavin, R. E. (1983). When does cooperative learning increase student achievement? Psychological Bulletin, 94, 429-445.

Slavin, R. E. (1984). Team assisted individualization: Cooperative learning and individualized instruction in the mainstreamed classroom. Remedial \& Special Education, 5(6), 33-42.

Slavin, R. E. (1995). Cooperative learning: Theory, research, and practice (2d ed.). Needham, MA: Allyn \& Bacon.

Slavin, R. E., \& Stevens, R. J. (1991). Cooperative learning and mainstreaming. In J. W. Lloyd, N. N. Singh, \& A. C. Repp (Eds.), The regular education initiative: Alternative perspectives on concepts, issues, and models (pp. 75-93). Sycamore, IL: Sycamore.

Tudge, J. (1992). Vygotsky, the zone of proximal development, and peer collaboration: Implications for classroom practice. In L. C. Moll (Ed.), Vygotsky and education: Instructional implications and applications of sociohistorical psychology, (pp. 155-172). New York: Cambridge University Press.

Vygotsky, L. S. (1978). Mind in society: The development of higher psychological processes (M. Cole, V. John-Steiner, S. Scribner, \& E. Souberman, Eds. \& Trans.). Cambridge, MA: Harvard University Press.

Wadsworth, B. J. (1984). Piaget's theory of cognitive and affective development (3d ed.). New York: Longman.

Wittrock, M. C. (1978). The cognitive movement in instruction. Educational Psychologist, 13, 15-29. 